\title{
Gene Transfer and Cloning of the Amino-Acid Transport System L from Human Cells
}

\author{
M. RAAFAT EL-GEWELY AND DALE L. OXENDER \\ Department of Biological Chemistry \\ University of Michigan \\ Ann Arbor, Michigan 48109
}

Neutral amino acids are transported into Chinese hamster ovary cells by three transport systems. ${ }^{1}$ System $\mathrm{A}$ and ASC are $\mathrm{Na}^{+}$-dependent and serve for lowmolecular-weight amino acids. System $\mathrm{L}$ is $\mathrm{Na}^{+}$-independent and serves for branchedchain amino acids and aromatic amino acids. Transport activity of System $L$ can be derepressed by severe starvation for leucine. It can also be derepressed in a temperature-sensitive leucyl-tRNA synthetase mutant cell line (CHO-025C1). ${ }^{2}$ Fusion of the $\mathrm{CHO}-025 \mathrm{C} 1$ mutant cell line with human leukocytes resulted in complemenation.

FIGURE 1. Human cosmid library (108K) DNA digested with EcoRI (lane 2). Lane 1 and lane 3 represent DNA size standards (lambda DNA digested with EcoRI and HindIII) and the cosmid vector, pCV108, digested with EcoRI, respectively.

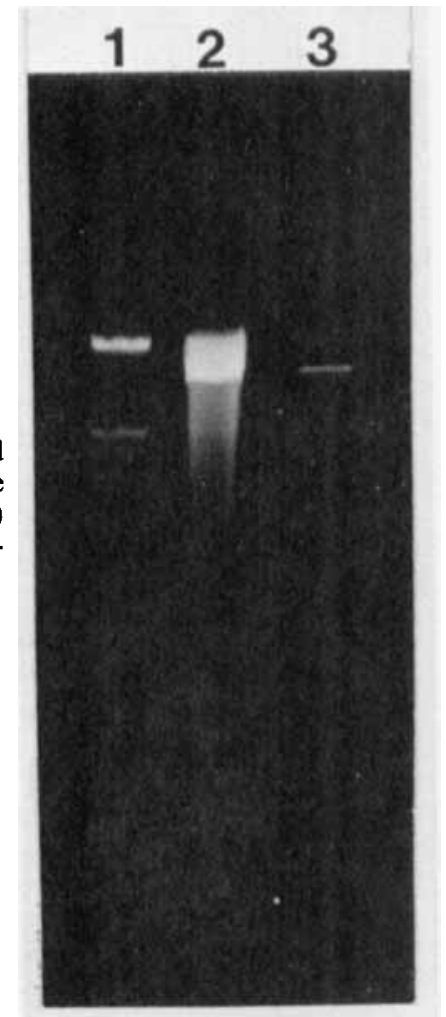


With this approach, it was shown that human chromosome 5 encodes leucyl-tRNA synthetase ${ }^{3}$ and human chromosome 20 encodes amino-acid transport System $L^{2}{ }^{2}$ The details of these experiments are reported in another article. ${ }^{4}$ We are presently attempting to clone and isolate human gene sequences that code for amino-acid System $\mathrm{L}$. For this approach, we are using the $\mathrm{CHO}-025 \mathrm{Cl}$ cell line, which requires high levels of leucine $(0.4 \mathrm{mM})$ to survive at $37^{\circ} \mathrm{C}$ or above. Human gene sequences contained in a cosmid library $(108 \mathrm{~K})$ obtained from Lau and $\mathrm{Kan}^{5}$ were transformed into the $\mathrm{CHO}$ cells and transformants were selected. The cosmid vector, pCV108, codes for G418 resistance when expressed in mammalian cells and codes for both kanamycin and ampicillin resistance when present in $E$. coli. DNA prepared from this library when

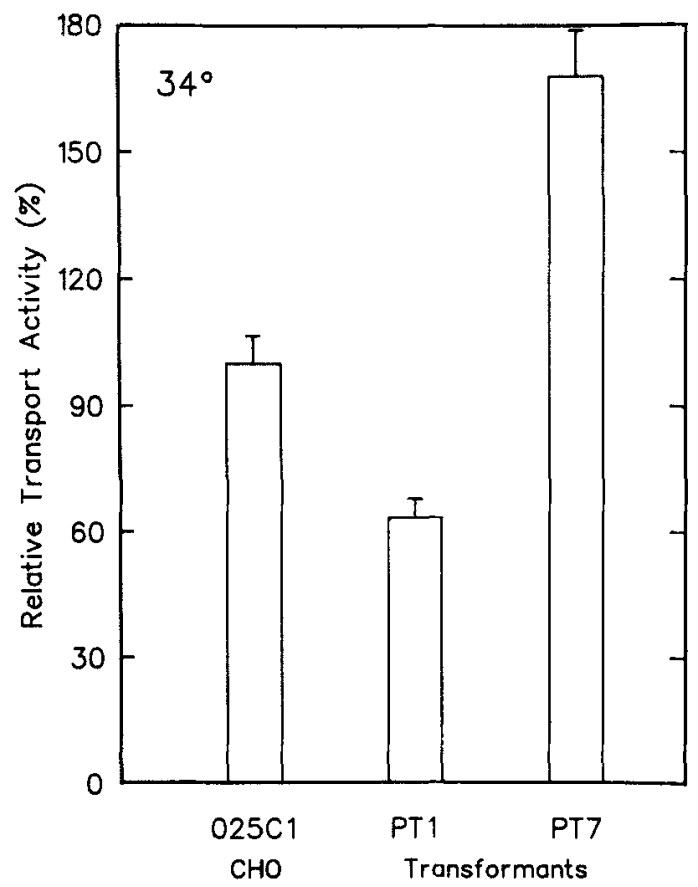

FIGURE 2. Leucine transport activity assay. Cell line PT7 is representative of a class of transformants that showed elevated levels of transport activity over the recipient cell line $(025 \mathrm{Cl})$. PT1 cell line represents a second class of transformants that have survived the screening processes, but does not have increased transport activity.

restricted with EcoRI gave one clear band representing the cosmid vector pCV108 and a smear of human DNA sequences of various lengths indicating a good representation of the complexity of the human genome (FIG. 1). First, transformants that were resistant to G418 were selected. In a second selection, survivors resistant to higher temperatures in the presence of low levels of leucine $(0.1 \mathrm{mM})$ were isolated. Some of these transformants have high levels of System L transport activity (FIG. 2) suggesting that human genes for leucine transport have been integrated into chromosomes of the transformed $\mathrm{CHO}$ cells. Another class of transformants that survived the selection procedures but did not have increased transport may represent transformants that have acquired the human leucyl-tRNA synthetase gene. Currently attempts are being made to rescue these human sequences by using a lambda in vitro packaging system. 


\section{REFERENCES}

1. Shotwell, M. A., D. W. Jayme, M. S. Kilberg \& D. L. Oxender. 1981. J. Biol. Chem. 256: $5422-5427$.

2. Lobaton, C. D., A. Moreno \& D. L. Oxender. 1984. Mol. Cell. Biol. 4: 475-483.

3. Giles, R. E., N. Shimizu \& F. H. Ruddle. 1980. Som. Cell Genet. 6: 667-687.

4. Oxender, D. L., E. J. Collarini, M. A. Shotwell, C. D. Lobaton, A. Moreno \& G. S. CAMPBell. 1985. Ann. N.Y. Acad. Sci. 456: 404-416 This volume.

5. LAU, Y. F. \& Y. W. KaN. 1983. Proc. Natl. Acad. Sci. USA 80: 5225-5229. 